\section{Foliar 2,4-D Application after Physiological Fruit Drop Reduces Fruit Splitting of Mandarin}

\author{
Ockert P.J. Stander ${ }^{1}$, Karen I. Theron ${ }^{2}$, and Paul J.R. Cronjé ${ }^{1}$
}

AdDitional INDEX wORDs. Citrus reticulata, physiological disorder, fruit size, rind strength, rind coarseness

SUMMARY. Various mandarin (Citrus reticulata) cultivars are prone to fruit splitting, a physiological disorder that entails cracking of the rind, starting from the stylar end of the fruit, with eventual splitting of the endocarp and abscission of the fruit. On two mandarin cultivars, Marisol and Mor, foliar applications of 2,4-dichlorophenoxyacetic acid $(2,4-D)$, calcium $(\mathrm{Ca})$, and potassium $(\mathrm{K})$ were evaluated over two growing seasons for efficacy to reduce fruit splitting in Paarl, South Africa (lat. $33^{\circ} 69^{\prime} \mathrm{S}$, long. $18^{\circ} 95^{\prime} \mathrm{E}$ ). Foliar treatment of $10 \mathrm{mg} \cdot \mathrm{L}^{-1} 2,4-\mathrm{D}$ directly after physiological fruit drop (APFD) compared with later dates in January and February, either alone or in combination with $K$, increased rind thickness and reduced fruit splitting of 'Marisol' and 'Mor' by up to 50\%, without negatively affecting internal fruit quality. Treatments increased rind thickness and rind strength throughout fruit development in addition to fruit diameter, length, and growth rate, with no significant effect on rind coarseness. There was a slight reduction in juice content and titratable acidity (TA), but no effect on the total soluble solids (TSS). Application of 2,4-D APFD is thought to increase rind integrity due to a direct strengthening effect on the rind during early stages of fruit development.

$\mathrm{F}$ ruit splitting of citrus (Citrus sp.) is a physiological disorder of the rind (Cronjé et al., 2014) and occurs in thin-rinded mandarin and mandarin hybrids (Almela et al., 1994), as well as sweet orange (Citrus sinensis) cultivars such as Navel (De Cicco et al., 1988) and Valencia (Borroto et al., 1981). Similarities in certain causal factors and physiological development of splitting exist between citrus and other commercial fruit species; however, the unique anatomy and physiology of citrus fruit add some complexity to understanding and controlling this disorder.

Several factors impede citrus fruit development and result in the rind being more susceptible to split; that is, $\mathrm{Ca}$ and $\mathrm{K}$ deficiency (Bar-Akiva, 1975; De Cicco et al., 1988; Erickson, 1957), warm and humid climatic conditions during early fruit development (Almela et al., 1994; Barry and Bower,

\footnotetext{
The authors thank Gerhard Van Vuuren for his assistance and for making available and allowing access to the orchard at Pearl Valley Estate, Paarl; Stephan Strauss from Mooikelder, Paarl; and Andre Swarts for his invaluable assistance in the field; as well as The Citrus Academy for financial support.

${ }^{1}$ Citrus Research International, Department of Horticultural Science, University of Stellenbosch, Post Bag X01, 7602 Matieland, Stellenbosch, South Africa

${ }^{2}$ Department of Horticultural Science, University of Stellenbosch, Post Bag X01, 7602 Matieland, Stellenbosch, South Africa
}

Corresponding author. E-mail: jakkie@sun.ac.za.
1997; Rabe et al., 1990), irregular water supply (De Cicco et al., 1988), and heavy crop load (Barry and Bower 1997; Rabe et al., 1990).

Control strategies have focused on the use of plant growth regulators and nutrients as foliar treatments. Foliar application of 2,4-D has been shown to reduce fruit splitting in 'Nova' mandarin and various sweet orange cultivars (Almela et al., 1994; Borroto et al., 1981; García-Luis et al., $2001)$ and to have a positive effect on fruit size (Agustí et al., 2002). However, in many instances, treatment results in development of enlarged oil glands in the flavedo, generally referred to as increased rind coarseness (Coggins and Hield, 1968). The reduction in fruit splitting in 'Marisol' following 15 and $25 \mathrm{mg} \cdot \mathrm{L}^{-1}$ 2,4-D applications during full bloom was accompanied by not only an increased rind coarseness but also attached styles at harvest, reducing the cosmetic appearance of treated fruit (Mupambi, 2010).

Foliar application of $2,4-\mathrm{D}$ is thought to reduce splitting by increasing rind strength as seen by the increased resistance to puncturing in 'Nova' mandarin (Almela et al., 1994). In addition, 2,4-dichlorophenoxyacetic acid altered the fruit dimensions (increased fruit length), relieving the tension at the splitting prone stylar end of the fruit. By combining 2,4-D with $\mathrm{K}$, the efficacy of 2,4-D was increased, resulting in larger fruit in both 'Shamouti' and 'Valencia' sweet orange (Erner et al., 1993), and reduced fruit splitting of 'Nova' mandarin (Greenberg et al., 2006).

The aim of this study was to evaluate the effects of foliar applications of 2,4-D on two split-prone mandarin cultivars at different phenological stages and at lower rates than previously reported, with the overarching aim of maintaining commercially acceptable internal and external fruit quality. The effect of 2,4-D foliar applications APFD on fruit growth rate was also evaluated. It is hypothesized that foliar application of 2,4-D APFD, either alone or in combination with $\mathrm{Ca}$ or $\mathrm{K}$, may reduce the severity of citrus fruit splitting in 'Marisol' and 'Mor', without compromising fruit quality and tree health.

\section{Materials and methods}

SPRAY MATERIAL AND APPLICATION METHOD. The less volatile dimethyl amine salt formulation of 2,4-D [10 $\mathrm{mg} \cdot \mathrm{L}^{-1}$ (Dow AgroSciences, Pretoria, South Africa)] was used to avoid any harmful drift of applications onto neighboring 2,4-D-sensitive crops. 2,4-dichlorophenoxyacetic acid was applied as a foliar spray on its own or in combination with $\mathrm{K}$ [ Bonus $\mathrm{N}-\mathrm{P}-\mathrm{K}$ (Haifa Chemicals, Cape Town, South Africa), a fully soluble, crystalline formulation of potassium nitrate $\left(\mathrm{KNO}_{3}\right)$,

\begin{tabular}{llll}
\hline $\begin{array}{l}\text { Units } \\
\text { To convert U.S. to SI, } \\
\text { multiply by }\end{array}$ & U.S. unit & SI unit & $\begin{array}{l}\text { To convert SI to U.S., } \\
\text { multiply by }\end{array}$ \\
\hline 29.5735 & $\mathrm{fl} \mathrm{oz}$ & $\mathrm{mL}$ & 0.0338 \\
0.3048 & $\mathrm{ft}$ & $\mathrm{m}$ & 3.2808 \\
3.7854 & gal & $\mathrm{L}$ & 0.2642 \\
25.4 & inch $(\mathrm{es})$ & $\mathrm{mm}$ & 0.0394 \\
4.4482 & $\mathrm{lbf}$ & $\mathrm{N}$ & 0.2248 \\
7.4892 & $\mathrm{oz} / \mathrm{gal}$ & $\mathrm{g} \cdot \mathrm{L}^{-1}$ & 0.1335 \\
62.5000 & $\mathrm{oz} / \mathrm{lb}$ & $\mathrm{g} \cdot \mathrm{kg}^{-1}$ & 0.0160 \\
1 & $\mathrm{ppm}$ & $\mathrm{mg} \cdot \mathrm{L}^{-1}$ & 1
\end{tabular}


with an analysis of $13 \mathrm{~N}-0.8 \mathrm{P}-$ $36.5 \mathrm{~K}]$ at $2.5 \%$ or $5 \%$, or $2 \% \mathrm{Ca}\{\mathrm{a}$ granular formulation of calcium nitrate $\left[\mathrm{Ca}\left(\mathrm{NO}_{3}\right)_{2}\right]$ (Omnia Nutriology, Bryanston, South Africa) with $155 \mathrm{~g} \cdot \mathrm{kg}^{-1}$ nitrogen $(\mathrm{N})$ and 195 $\left.\mathrm{g} \cdot \mathrm{kg}^{-1} \mathrm{Ca}\right]$.

All foliar treatments were applied with a nonionic wetting agent (BreakThru $^{\circledR}$; Villa Crop Protection, Kempton Park, South Africa) with the active ingredient polyether-polymethylsiloxanecopolymer $\left(1000 \mathrm{~g} \cdot \mathrm{L}^{-1}\right)$ at a rate of $5 \mathrm{~mL}$ per $100 \mathrm{~L}$ spray solution. Applications were made using a hand-gun sprayer until runoff, at $\approx 10 \mathrm{~L}$ per tree and buffer trees were left untreated between trees in the orchard row. For all the control treatments, trees were sprayed directly APFD with water and the nonionic wetting agent.

PLANT MATERIAL AND TREATMENTS. The experiment was conducted over two consecutive seasons (2010-11 and 2011-12) in commercial mandarin orchards (1520 years old) of 'Marisol' and 'Mor' in Paarl, South Africa (lat. $33^{\circ} 69^{\prime}$ S, long. $\left.18^{\circ} 95^{\prime} \mathrm{E}\right)$, a citrus producing region in the Western Cape province that experiences Mediterranean climatic conditions. Trees in both orchards were budded onto 'Carrizo' citrange (C. sinensis $\times$ Poncirus trifoliata) rootstock. Foliar treatments for 'Marisol' were applied directly APFD \pm $45 \mathrm{~d}$ after full bloom (DAFB) at an average fruitlet diameter of 13 to $17 \mathrm{~mm}$, as well as at a later timing, at an average fruitlet diameter of 33 to $35 \mathrm{~mm} \pm 90$ DAFB (January) and 41 to $43 \mathrm{~mm} \pm 120$ DAFB (February). Foliar applications for 'Mor' were done directly APFD at an average fruitlet diameter of $15 \pm 45 \mathrm{DAFB}$, as well as 23 to $25 \mathrm{~mm} \pm 90$ DAFB (January) and 34 to $36 \mathrm{~mm} \pm 120$ DAFB (February). Trees were chosen that were uniform in size and crop load, and the treatments were applied to the same trees during the following season.

Data collection. Trees were monitored for initiation of fruit splitting, and split fruit were removed and counted at two to three weekly intervals from initiation of split (start of February) until harvest. Fruit splitting was expressed as the total number of split fruit removed and counted per tree and not as the percentage of the total fruit per tree, as the total yield per tree was not determined. In all the experiments, 10 fruit were randomly selected at a height of 1 to $3 \mathrm{~m}$ and tagged on trees receiving a $2,4-\mathrm{D}$ application directly after the chemical treatments were applied. The diameters of these tagged fruit were measured at monthly intervals until harvest to calculate fruit growth rate (millimeters per day). During 2012, from 'Marisol' trees treated with 2,4-D and $2,4-\mathrm{D}+\mathrm{K}$ and the control, five fruit were picked per tree on 9 Jan. (before visual fruit split initiation), 8 Feb. (start of visual fruit split initiation), 6 Mar. (1 month after visual fruit split initiation), and 4 April (commercial harvest) for microscopic (ERc5s; Carl Zeiss, Göttingen, Germany) photographic comparisons of the stylar end, as well as rind strength determination. Rind strength was measured and expressed as rind cutting force (Newtons) by cutting two $10 \times 10-\mathrm{mm}$ pieces of the rind from opposite cheeks at the equatorial region and one from the stylar end of a five-fruit replicate. The rind pieces were then positioned on a texture analyzer (TAXT2i; Stable Microsystems, Surrey, England) HDP/BSK blade set. A blade set knife of the texture analyzer attached to the probe carrier was used to cut the rind pieces after calibrating the load cell to $250 \mathrm{~N}$ and cutting at a speed of $1 \mathrm{~mm} \cdot \mathrm{s}^{-1}$.

A 12-fruit sample was collected per tree at commercial harvest, six from each row-side to determine internal and external fruit quality. Rind coarseness was scored on a scale of one to four, with one being smooth and four being extremely coarse (enlarged oil glands of the flavedo). An electronic calliper (CD-6" C; Mitutoyo Corp, Tokyo, Japan) was used to measure fruit diameter and fruit length in millimeter. Fruit were cut into half along the longitudinal plane to measure rind thickness in millimeter with the electronic calliper at the equatorial region and stylar end, before being juiced to determine juice content (percentage), TSS (percentage) (PR-32 Palette electronic refractometer; Atago Co, Tokyo, Japan), and TA.

STATISTICAL DESIGN AND ANALYSIS. All treatments were applied in a randomized complete block design with 10 single-tree replicates per treatment. Buffer trees between treated trees as well as buffer rows were included in the trial layout. Statistical analyses of variance were performed using PROC GLM of the SAS (version
9.1; SAS Institute, Cary, NC). Mean separation was done by the least significant difference test, where applicable $(P=0.05)$.

\section{Results and discussion}

Fruit SPLITTING. In 2012, splitting was reduced in both cultivars by 2,4-D application compared with the control. Although a similar, but nonsignificant trend was evident in 2011, this reduction of fruit splitting in mandarin is in agreement with Greenberg et al. (2006) who reported lower incidence of splitting in 'Nova' mandarin following a 2,4-D application at $13 \mathrm{~mm}$ fruit diameter, albeit with a higher concentration of $40 \mathrm{mg} \cdot \mathrm{L}^{-1} \quad 2,4-\mathrm{D}$, whereas Almela et al. (1994) reported successful reduction of splitting of 'Nova' mandarin with two tank-mix applications of 2,4-D (20 mg. $\left.\mathrm{L}^{-1}\right)$ and $\mathrm{GA}_{3}\left(20 \mathrm{mg} \cdot \mathrm{L}^{-1}\right)$ at later fruit developmental stages; that is, 30 and $60 \mathrm{~d}$ before initiation of fruit splitting.

For 'Marisol', fruit splitting was significantly reduced by application of $2,4-\mathrm{D}$ at a similar stage in a tank-mix application with $\mathrm{K}(5 \%)$ in 2011 and 2012 , as well as with a lower dosage of $\mathrm{K}(2.5 \%)$ in 2012 (Table 1$)$, whereas only some small differences between treatments occurred in 2011 for 'Mor'. In 2012, APFD-application of 2,4-D alone, as well as the tank-mix with $\mathrm{K}$ $(5 \%)$ and $\mathrm{Ca}$, significantly reduced fruit splitting of 'Mor' compared with the control treatment (Table 1). In both cultivars, the positive impact of 2,4-D was reduced if applied in January, no significant effect obtained when delayed until February, and in some instances increased the number of split fruit (Table 1).

Foliar application of $\mathrm{Ca}$ was ineffective in reducing splitting, which is in contradiction with Almela et al. (1994) and Sdoodee and Chiarawipa (2005). However, in citriculture, the best strategy to improve Ca content of fruit is still to optimize root uptake and transport via the transpiration stream in the xylem as $\mathrm{Ca}$ is not readily absorbed from the fruit surface (Hanger, 1979).

FRUIT DEVELOPMENT AND MORPHOLOGY. For both cultivars, the application of 2,4-D APFD increased fruit growth rate significantly in comparison with the control (Table 2), whereas the later applications of 2,4$\mathrm{D}$ had no or little effect, and in some instances reduced fruit growth rate. 
Table 1. The effect of 2,4-dichlorophenoxyacetic acid (2,4-D), potassium (K), and calcium (Ca) applied alone or combined as foliar treatments [ $10 \mathrm{~L}(2.6 \mathrm{gal})$ per tree] at different timings [after physiological fruit drop (APFD), January, and February] on total fruit splitting of two mandarin cultivars (Marisol and Mor) in 2011 and 2012 at Paarl, South Africa (lat. $33^{\circ} 69^{\prime} \mathrm{S}$, long. $\left.18^{\circ} 95^{\prime} \mathrm{E}\right)$.

\begin{tabular}{|c|c|c|c|c|c|c|}
\hline \multirow[b]{2}{*}{ Chemical $^{\mathrm{z}}$} & \multirow[b]{2}{*}{ Concn of chemicaly } & \multirow[b]{2}{*}{ Timing of treatment } & \multicolumn{4}{|c|}{ Avg split fruit (no./tree) } \\
\hline & & & 'Marisol' 2011 & 'Mor' 2011 & 'Marisol' 2012 & 'Mor' 2012 \\
\hline Control & - & - & $209 a b c^{x}$ & $8 \mathrm{ab}$ & $68 \mathrm{a}$ & $31 \mathrm{a}$ \\
\hline $\mathrm{K}^{\mathrm{v}}$ & $2.5 \%$ & APFD & - & & $42 \mathrm{~b}$ & - \\
\hline $\mathrm{K}$ & $5 \%$ & APFD & $154 \mathrm{bcd}$ & $5 \mathrm{ab}$ & $33 \mathrm{~b}$ & $26 \mathrm{a}$ \\
\hline $\mathrm{Ca}^{\mathrm{u}}$ & $2 \%$ & APFD & $237 \mathrm{ab}$ & $9 \mathrm{a}$ & - & $23 \mathrm{ab}$ \\
\hline $2,4-\mathrm{D}+\mathrm{Ca}$ & $10 \mathrm{mg} \cdot \mathrm{L}^{-1}+2 \%$ & APFD & $151 \mathrm{bcd}$ & $5 \mathrm{~b}$ & - & $13 \mathrm{c}$ \\
\hline $2,4-\mathrm{D}$ & $10 \mathrm{mg} \cdot \mathrm{L}^{-1}$ & January & $273 \mathrm{a}$ & 8 a & - & $20 \mathrm{~b}$ \\
\hline $2,4-\mathrm{D}$ & $10 \mathrm{mg} \cdot \mathrm{L}^{-1}$ & February & $184 \mathrm{bcd}$ & $7 \mathrm{ab}$ & - & $26 \mathrm{a}$ \\
\hline$P$ value & & & 0.0038 & 0.0140 & 0.0021 & 0.0001 \\
\hline
\end{tabular}

${ }^{2}$ Nonionic wetting agent with $1000 \mathrm{~g} \cdot \mathrm{L}^{-1}(133.5 \mathrm{oz} / \mathrm{gal})$ of polyether-polymethylsiloxanecopolymer (Break-Thru ${ }^{\circledR}$, Villa Crop Protection, Kempton Park, South Africa) was applied with every chemical at $5 \mathrm{~mL}$ per $100 \mathrm{~L}(0.64 \mathrm{fl} \mathrm{oz} / 100 \mathrm{gal})$ spray solution.

${ }^{y} \mathrm{l} \mathrm{mg} \cdot \mathrm{L}^{-1}=1 \mathrm{ppm}$.

${ }^{x}$ Means with a different letter within a column differ significantly at the $5 \%$ level (least significant difference).

"Dimethyl amine salt formulation of 2,4-D (Dow AgroSciences, Pretoria, South Africa).

${ }^{v}$ Fully soluble, crystalline formulation of potassium nitrate $\left(\mathrm{KNO}_{3}\right)$, with an analysis of $13 \mathrm{~N}-0.8 \mathrm{P}-36.5 \mathrm{~K}$ (Bonus N-P-K; Haifa Chemicals, Cape Town, South Africa).

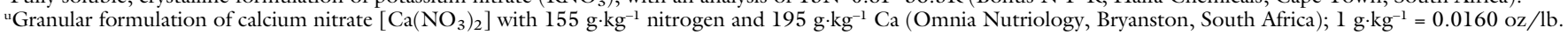

Table 2. The effect of $10 \mathrm{mg} \cdot \mathrm{L}^{-1}(\mathrm{ppm}) 2,4$-dichlorophenoxyacetic acid $(2,4-\mathrm{D})$ applied as foliar treatment [10 L $(2.6 \mathrm{gal})$ per tree] at different timings [after physiological fruit drop (APFD), January, and February] on fruit growth rate of two mandarin cultivars (Marisol and Mor) in 2011 and 2012 at Paarl, South Africa (lat. $33^{\circ} 69^{\prime} \mathrm{S}$, long. $18^{\circ} 95^{\prime} \mathrm{E}$ ).

\begin{tabular}{|c|c|c|c|}
\hline \multirow[b]{2}{*}{ Chemical $^{\mathrm{z}}$} & \multirow[b]{2}{*}{ Timing of treatment } & \multicolumn{2}{|c|}{ Fruit growth rate $2011\left(\mathrm{~mm} \cdot \mathrm{d}^{-1}\right)^{\mathrm{y}}$} \\
\hline & & 'Marisol' & 'Mor' \\
\hline Control & - & $0.28 \mathrm{~b}^{\mathrm{x}}$ & $0.24 \mathrm{~b}$ \\
\hline $2,4-D^{w}$ & APFD & $0.30 \mathrm{a}$ & $0.26 \mathrm{a}$ \\
\hline $2,4-\mathrm{D}$ & January & $0.27 \mathrm{~b}$ & $0.23 \mathrm{c}$ \\
\hline $2,4-\mathrm{D}$ & February & $0.27 \mathrm{~b}$ & $0.23 \mathrm{c}$ \\
\hline$P$ value & & 0.0001 & 0.0312 \\
\hline
\end{tabular}

\begin{tabular}{lccc} 
& & \multicolumn{2}{c}{ Fruit growth rate $2012\left(\mathbf{m m} \cdot \mathbf{d}^{-\mathbf{1}}\right)$} \\
\cline { 3 - 4 } Chemical & Timing of treatment & 'Marisol' & 'Mor' \\
\hline Control & - & $0.35 \mathrm{~b}$ & $0.20 \mathrm{c}$ \\
$2,4-D$ & APFD & $0.37 \mathrm{a}$ & $0.22 \mathrm{a}$ \\
$2,4-\mathrm{D}$ & January & - & $0.21 \mathrm{~b}$ \\
$2,4-\mathrm{D}$ & February & - & $0.21 \mathrm{~b}$ \\
$P$ value & & 0.0097 & 0.0401 \\
\hline
\end{tabular}

${ }^{2}$ Nonionic wetting agent with $1000 \mathrm{~g} \cdot \mathrm{L}^{-1}(133.5 \mathrm{oz} / \mathrm{gal})$ of polyether-polymethylsiloxanecopolymer (BreakThru $^{\circledast}$, Villa Crop Protection, Kempton Park, South Africa) was applied with every chemical at $5 \mathrm{~mL}$ per $100 \mathrm{~L}$ $(0.64 \mathrm{fl} \mathrm{oz} / 100 \mathrm{gal})$ spray solution.

${ }^{y}$ Calculated from mo.ly measurement of fruit diameter; $1 \mathrm{~mm}=0.0394$ inch.

${ }^{x}$ Means with a different letter within a column differ significantly at the $5 \%$ level (least significant difference).

"Dimethyl amine salt formulation of 2,4-D (Dow AgroSciences, Pretoria, South Africa).

In 2012 , there were no significant differences in fruit diameter of 'Marisol' between the single 2,4-D, $2,4-\mathrm{D}+\mathrm{K}(5 \%)$ treatment and the control at the first evaluation date on 9 Jan. (Fig. 1A). Thereafter, both treatments resulted in significantly larger fruit diameter in February, March, and April than the control treatment, which concurs with
El-Otmani et al. (1993) and Greenberg et al. (2006). The increase in fruit size by $2,4-\mathrm{D}$ could be due to a dual action whereby it increases the rind thickness, as well as juice vesicle cell expansion (El-Otmani et al., 1993). In addition to increased sink strength of treated fruit, 2,4-D treatment can increase transport effectiveness of water, nutrients, and assimilates by increasing the capacity of the vascular system that connects the source (leaves) to the sink (developing fruit) (Bustan et al., 1995). Mesejo et al. (2003) reported an increase in the pedicel diameter of mandarin resulting from an increase in the central xylem cylinder as well as the number and the average diameter of xylem vessels after foliar application of $15 \mathrm{mg} \cdot \mathrm{L}^{-1} 2,4-\mathrm{D}$ APFD.

Fruit length was significantly longer for both foliar sprays in comparison with the control, on all the evaluation dates [January to April (Fig. 1B)]. The diameter:length ratio differed significantly between the two treatments and the control in February and March, with the control fruit having higher ratio values, indicating these fruit were more oblate than the 2,4-D-treated fruit. Considine and Brown (1981) showed that the tension on fruit pericarp tissue exerted at the polar regions (stylar- and stemends) is highest, which in addition to a thinner stylar-end rind and styleabscission scar, could lead to a more susceptible rind for the initiation of citrus fruit splitting in this particular area. Application of 2,4-D on its own and in combination with $\mathrm{K}$ increased fruit length (Fig. 1), making fruit less oblate and thereby possibly relieving the tension exerted on the stylar end of the fruit, and reducing the susceptibility to fruit splitting.

Stimulation of cell expansion by 2,4-D treatments (Mitchell, 1961) 


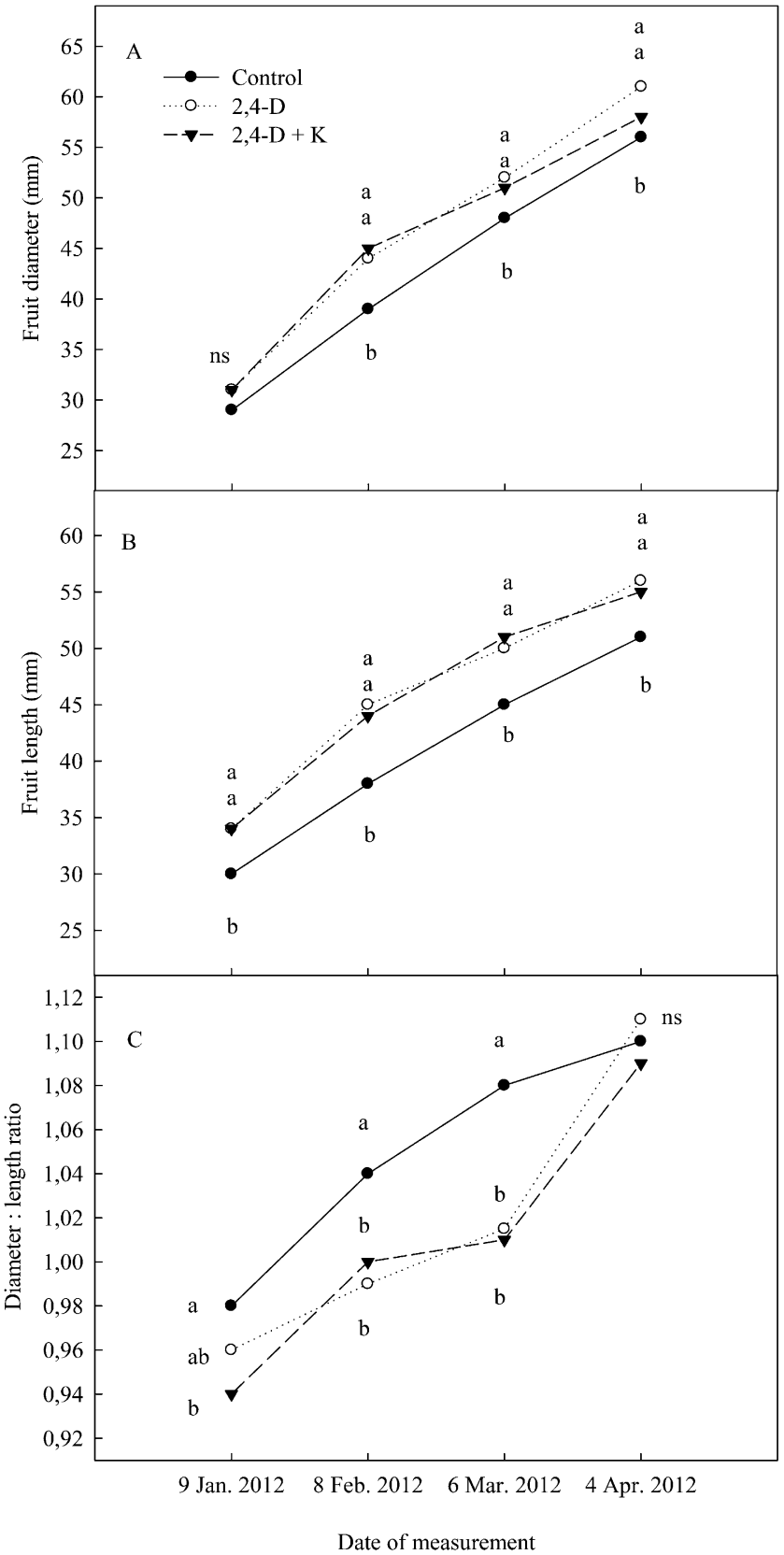

Fig. 1. (A) Average fruit diameter, (B) fruit length, and (C) diameter:length ratio in 2012 of 'Marisol' clementine mandarin fruit treated with a foliar application of 10 $\mathrm{mg} \cdot \mathrm{L}^{-1}(\mathrm{ppm})$ 2,4-dichlorophenoxyacetic acid (2,4-D) and $10 \mathrm{mg} \cdot \mathrm{L}^{-1} 2,4-\mathrm{D}+5 \%$ potassium (K applied as $13 \mathrm{~N}-0.8 \mathrm{P}-36.5 \mathrm{~K}$ ) after physiological fruit drop, compared with control, untreated fruit. Means with a different letter within an observation date differ significantly at the $5 \%$ level (ns = no significant differences); $1 \mathrm{~mm}=0.0394$ inch .

may have been responsible for the increase in rind strength of treated fruit, as the application of $10 \mathrm{mg} \cdot \mathrm{L}^{-1}$ 2,4-D on 'Marisol' resulted in a significantly stronger rind. Rind strength at the stylar end of the fruit was increased by 2,4-D treatments in comparison with the control, ranging from $5 \%$ to $7 \%$ in January, $18 \%$ to $20 \%$ in February, and $25 \%$ to $30 \%$ in March (Fig. 2), concurring with a similar effect obtained on 'Nova' mandarin by Almela et al. (1994).

The formation of a uniform abscission layer without tears between the style and stylar end of the rind seems to be important to prevent stylar-end fruit splitting, as the small lesion is thought to be the starting point for this disorder. Natural auxins in plant tissue such as 3-indoleacetic acid primarily regulate abscission by blocking the capacity of ethylene to stimulate the abscission of plant material (Borroto et al., 1981; Goren, 1993). The 2,4-D treatments APFD as reported here are thought to have allowed for a more gradual style abscission to occur. Visual evaluation of the stylar end region of 2,4-D-treated fruit revealed the rind to be slightly elevated, thickened, and without microcracks (Fig. 3). Stemming from these observations, it is thought that the treatment could have stimulated rind growth in this area, extending the floral axis beyond the abscission zone of the style, resulting in a compact, solid tissue after style abscission (Fig. 3C and D). In control fruit, the floral axis did not extend toward the style and after abscission of the style, a cavity was formed instead of solid rind tissue (Fig. 3A and B), which could possibly compromise rind integrity.

Fruit QUALITy. The thinner stylar-end fruit rind in 2011 (1.30 $\mathrm{mm}$ ) compared with $2012(1.50 \mathrm{~mm})$ (Table 3 ) could partly explain the higher severity of the disorder in 2011. This concurs with Almela et al. (1994) who reported an inverse relationship between rind thickness and fruit splitting, with an increase in number of split fruit as the average rind thickness decreased. Environmental and cultural practices have an effect on rind thickness and are related to split incidence; that is, very warm and humid conditions (Almela et al., 1994), as well as mineral nutrients and water stress (De Cicco et al., 1988). In 2011, for 'Marisol', rind thickness at the stylar end was not significantly affected by any of the treatments except $\mathrm{K}(5 \%)$, while rind thickness at the equatorial region was decreased by $\mathrm{Ca}$ (Table 3 ). However, in 2012, all the treatments increased fruit rind thickness at the stylar end, except $\mathrm{K}(5 \%)$, and also at the equatorial region of the fruit with the exception of the tank-mix application of 2,4-D and $\mathrm{K}(2.5 \%)$ (Table 3 ). For 'Mor', all treatments with $\mathrm{Ca}$ or $\mathrm{K}$, as well as when tank-mixed with 2,4-D significantly increased rind thickness at the stylar end, whereas 2,4-D applied alone directly APFD increased rind thickness at the equatorial region of the fruit in 2012 (Table 3).

In citriculture, preharvest treatment with $2,4-\mathrm{D}$ at very high concentrations $\left(>20 \mathrm{mg} \cdot \mathrm{L}^{-1}\right)$ lead to the 


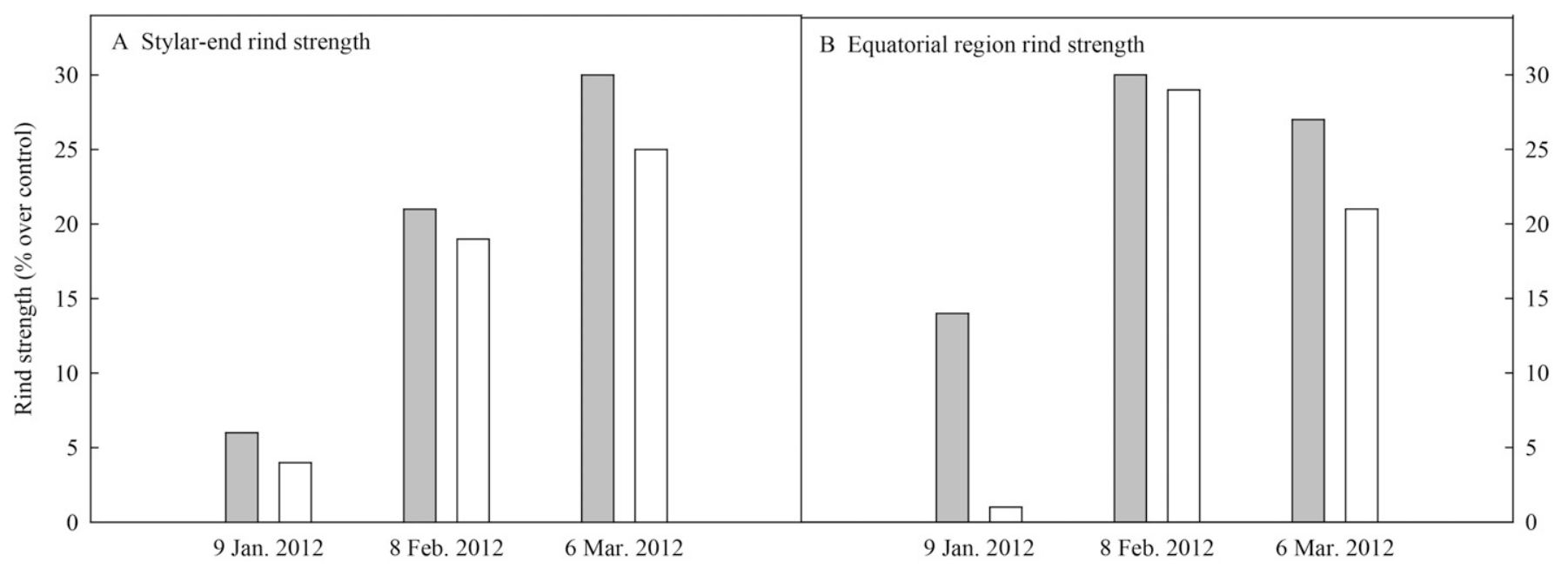

Date of measurement

Fig. 2. The effect of a foliar application of $10 \mathrm{mg} \cdot \mathrm{L}^{-1}(\mathrm{ppm}) 2,4$-dichlorophenoxyacetic acid (2,4-D) and $10 \mathrm{mg} \cdot \mathrm{L}^{-1} 2,4-\mathrm{D}+5 \%$ potassium (K applied as $13 \mathrm{~N}-0.8 \mathrm{P}-36.5 \mathrm{~K}$ ) after physiological fruit drop, on (A) rind strength at the stylar end of 'Marisol' clementine mandarin and (B) at the equatorial region of treated fruit in 2012, expressed as the percentage increase over control, untreated fruit. Rind strength was measured by cutting two $10 \times 10-\mathrm{mm}$ pieces of the rind from opposite cheeks at the equatorial region and one from the stylar end of a five-fruit replicate. The rind pieces were then positioned on a texture analyzer (TAXT2i; Stable Microsystems, Surrey, England) HDP/BSK blade set. A blade set knife of the texture analyzer attached to the probe carrier was used to cut the rind pieces after calibrating the load cell to $250 \mathrm{~N}(56.2 \mathrm{lbf})$ and cutting at a speed of $1 \mathrm{~mm} \cdot \mathrm{s}^{-1}$; $1 \mathrm{~mm}=0.0394$ inch.

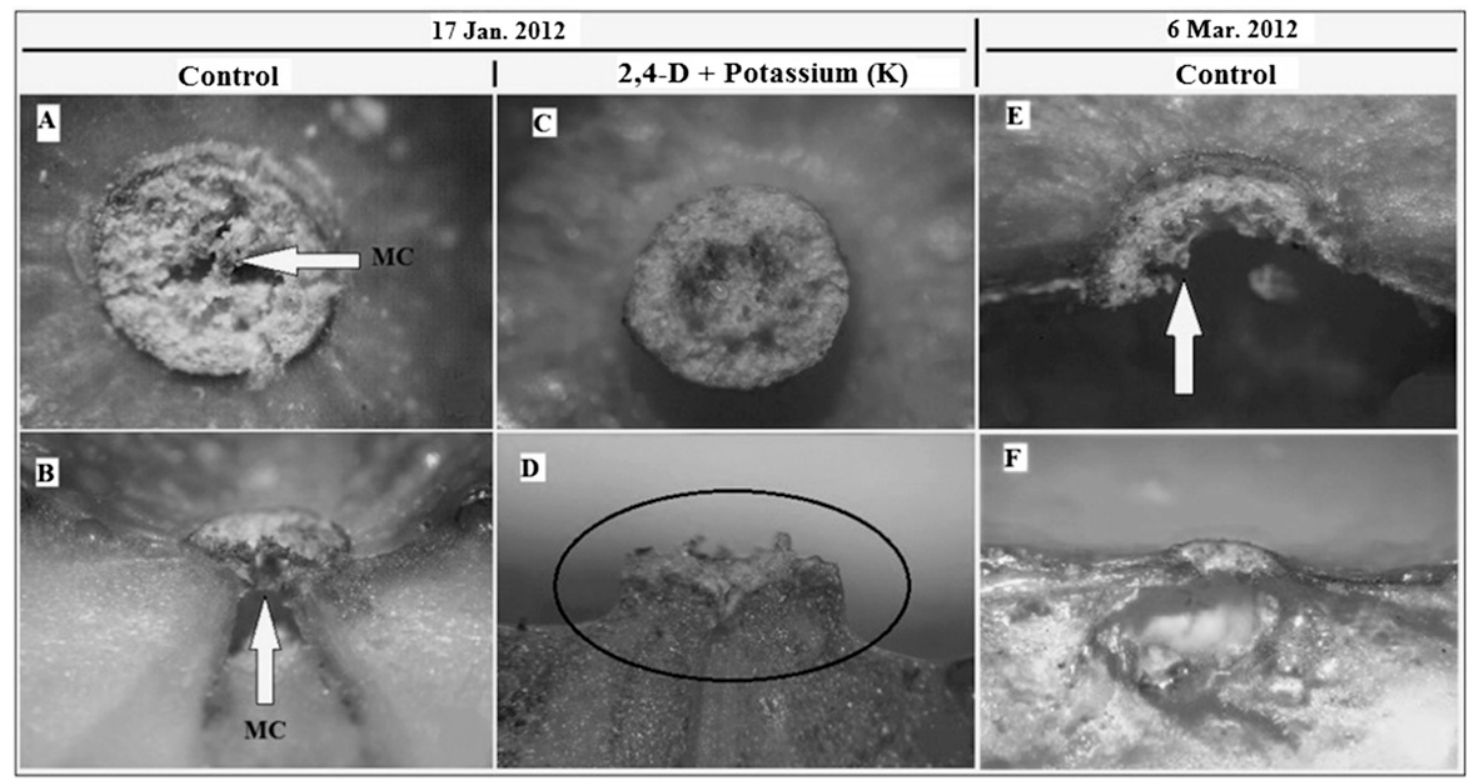

Fig. 3. Control fruit showing microcracks (MC) at the stylar end of 'Marisol' clementine mandarin fruit, 2 weeks before visual fruit split initiation, on 17 Jan. 2012 (A and B). No microcracks were visible at the stylar ends of fruit treated with a foliar application of $10 \mathrm{mg} \cdot \mathrm{L}^{-1}(\mathrm{ppm}) 2,4$-dichlorophenoxyacetic acid $(2,4-\mathrm{D})+5 \%$ potassium $(\mathrm{K}$ applied as $13 \mathrm{~N}-0.8 \mathrm{P}-36.5 \mathrm{~K})$ after physiological fruit drop, on the same evaluation date. The apical floral meristem extended into the style of the fruit (C and $\mathrm{D})$ (circle), which after style abscission, resulted in a compact, solid tissue, making the treated fruit less prone to fruit splitting. On 6 Mar. 2012, the split lesion on the control fruit (arrow) extended into the flavedo and albedo, which eventually manifested as fruit splitting $(\mathrm{E}$ and $\mathrm{F})$. 
Table 3. The effect of 2,4-dichlorophenoxyacetic acid (2,4-D), potassium (K), and calcium (Ca) applied alone or combined as foliar treatment [ $10 \mathrm{~L}$ (2.6 gal) per tree] at different timings [after physiological fruit drop (APFD), January, and February] on rind thickness at the stylar end (S-E) and equatorial region (EQ-R) of fruit from two mandarin cultivars (Marisol and Mor) in 2011 and 2012 at Paarl, South Africa (lat. $33^{\circ} 69^{\prime} \mathrm{S}$, long. $18^{\circ} 95^{\prime} \mathrm{E}$ ).

\begin{tabular}{|c|c|c|c|c|c|c|c|c|c|c|}
\hline \multirow[b]{3}{*}{ Chemical $^{\mathrm{z}}$} & \multirow{3}{*}{$\begin{array}{l}\text { Concn of } \\
\text { chemical }^{y}\end{array}$} & \multirow{3}{*}{$\begin{array}{l}\text { Timing of } \\
\text { treatment }\end{array}$} & \multicolumn{8}{|c|}{ Rind thickness at the S-E and EQ-R $(\mathrm{mm})^{\mathrm{x}}$} \\
\hline & & & \multicolumn{2}{|c|}{ 'Marisol' 2011 } & \multicolumn{2}{|c|}{ 'Mor' 2011} & \multicolumn{2}{|c|}{ 'Marisol' 2012} & \multicolumn{2}{|c|}{ 'Mor' 2012} \\
\hline & & & S-E & EQ-R & S-E & EQ-R & S-E & EQ-R & S-E & EQ-R \\
\hline $2,4-\mathrm{D}^{\mathrm{v}}$ & $10 \mathrm{mg} \cdot \mathrm{L}^{-1}$ & APFD & 1.20 & $2.01 \mathrm{abc}$ & $2.18 \mathrm{a}$ & 5.21 & $1.65 \mathrm{~b}$ & $2.32 \mathrm{bc}$ & $1.73 \mathrm{~b}$ & $2.70 \mathrm{a}$ \\
\hline $\mathrm{K}^{\mathrm{u}}$ & $2.5 \%$ & APFD & - & - & - & - & $1.60 \mathrm{bc}$ & $2.39 \mathrm{ab}$ & - & - \\
\hline K & $5 \%$ & APFD & 2.02 & $2.15 \mathrm{a}$ & $2.16 \mathrm{a}$ & 5.51 & $1.83 \mathrm{a}$ & $2.47 \mathrm{a}$ & $2.53 \mathrm{a}$ & $2.38 \mathrm{~b}$ \\
\hline $2,4-\mathrm{D}+\mathrm{K}$ & $10 \mathrm{mg} \cdot \mathrm{L}^{-1}+5 \%$ & APFD & 1.16 & $2.01 \mathrm{bc}$ & $2.01 \mathrm{a}$ & 5.22 & $1.70 \mathrm{ab}$ & $2.34 \mathrm{bc}$ & $2.51 \mathrm{a}$ & $2.34 \mathrm{~b}$ \\
\hline $2,4-\mathrm{D}+\mathrm{Ca}$ & $10 \mathrm{mg} \cdot \mathrm{L}^{-1}+2 \%$ & APFD & 1.25 & $2.00 \mathrm{abc}$ & $2.15 \mathrm{a}$ & 5.24 & - & - & $2.46 \mathrm{a}$ & $2.29 \mathrm{~b}$ \\
\hline $2,4-\mathrm{D}$ & $10 \mathrm{mg} \cdot \mathrm{L}^{-1}$ & January & 1.11 & $1.93 \mathrm{bc}$ & $2.16 \mathrm{a}$ & 5.20 & - & 一 & $2.21 \mathrm{ab}$ & $2.24 \mathrm{~b}$ \\
\hline $2,4-\mathrm{D}$ & $10 \mathrm{mg} \cdot \mathrm{L}^{-1}$ & February & 1.40 & $2.07 \mathrm{ab}$ & $2.09 \mathrm{a}$ & 5.23 & - & - & $1.89 \mathrm{~b}$ & $2.34 \mathrm{~b}$ \\
\hline$P$ value & & & 0.2895 & 0.0264 & 0.0432 & 0.4325 & 0.0287 & 0.0103 & 0.0005 & 0.0007 \\
\hline
\end{tabular}

${ }^{2}$ Nonionic wetting agent with $1000 \mathrm{~g} \cdot \mathrm{L}^{-1}(133.5 \mathrm{oz} / \mathrm{gal})$ of polyether-polymethylsiloxanecopolymer (Break-Thru ${ }^{\circledR}$, Villa Crop Protection, Kempton Park, South Africa) was applied with every chemical at $5 \mathrm{~mL}$ per $100 \mathrm{~L}(0.64 \mathrm{fl} \mathrm{oz} / 100 \mathrm{gal})$ spray solution.

${ }^{y} \mathrm{l} \mathrm{mg} \cdot \mathrm{L}^{-1}=1 \mathrm{ppm}$.

${ }^{\mathrm{x}} \mathrm{l} \mathrm{mm}=0.0394$ inch.

${ }^{\text {w} M e a n s ~ w i t h ~ a ~ d i f f e r e n t ~ l e t t e r ~ w i t h i n ~ a ~ c o l u m n ~ d i f f e r ~ s i g n i f i c a n t l y ~ a t ~ t h e ~} 5 \%$ level (least significant difference).

'Dimethyl amine salt formulation of 2,4-D (Dow AgroSciences, Pretoria, South Africa).

"Fully soluble, crystalline formulation of potassium nitrate $\left(\mathrm{KNO}_{3}\right)$, with an analysis of $13 \mathrm{~N}-0.8 \mathrm{P}-36.5 \mathrm{~K}$ (Bonus N-P-K; Haifa Chemicals, Cape Town, South Africa).

${ }^{t}$ Granular formulation of calcium nitrate $\left[\mathrm{Ca}\left(\mathrm{NO}_{3}\right)_{2}\right]$ with $155 \mathrm{~g} \cdot \mathrm{kg}^{-1}$ nitrogen and $195 \mathrm{~g} \cdot \mathrm{kg}^{-1} \mathrm{Ca}\left(\mathrm{Omnia}\right.$ Nutriology, Bryanston, South Africa); $1 \mathrm{~g} \cdot \mathrm{kg}{ }^{-1}=0.0160 \mathrm{oz} / \mathrm{lb}$.

development of excessively thick and coarse rinds of treated fruit due to enlarged oil glands in the flavedo (Stewart et al., 1951). The synthetic auxin 2,4-D is rapidly absorbed and translocated in the phloem to young meristematic tissue and accumulates in sink organs such as young leaves, flowers, or fruitlets where it stimulates cell expansion (Ashton and Monaco, 1991; Mitchell, 1961). Mupambi (2010) found that applications of 25 $\mathrm{mg} \cdot \mathrm{L}^{-1}$ at full bloom, as well as 15 and $25 \mathrm{mg} \cdot \mathrm{L}^{-1}$ at petal drop reduced split of 'Marisol', but increased rind coarseness. However, with the lower concentration $\left(10 \mathrm{mg} \cdot \mathrm{L}^{-1}\right)$ and later timing (APFD) of 2,4-D application reported in this study, none of the treatments had a significant effect on rind coarseness in any season (data not shown).

There were no significant differences in the TSS, TA, and TSS:TA ratio between treated or control fruit, and although not significant, it was noted that all the treatments with 2,4-D marginally reduced juice content of the fruit (data not shown).

\section{Conclusion}

Foliar application of $10 \mathrm{mg} \cdot \mathrm{L}^{-1}$ 2,4-D directly APFD reduced the number of split fruit in 'Marisol' by $42 \%$ in 2011 and $50 \%$ in 2012. In 'Mor', the number of split fruit was reduced by $63 \%$ in 2011 and $50 \%$ in
2012. In addition, foliar application APFD of 2,4-D and 2,4-D + K treatments increased rind thickness at the stylar end of the fruit resulting in a solid, compact tissue at the stylarend region of the fruit and therefore increasing the strength of the fruit rind. In addition, successful treatments modified the fruit shape (reduced diameter:length ratio), resulting in less split-prone fruit and increased the growth rate (millimeters per day, measured from fruit diameter) of 'Marisol' and 'Mor' significantly. Successful increase in growth rate by $2,4-\mathrm{D}$ application APFD is thought to be a result of a combination of an increase in rind thickness, as well as increased expansion of juice vesicles of the pulp. Except for a slight, but nonsignificant reduction of juice content and TA, there was no commercially significant negative effect of the treatments on TSS and TSS:TA ratio. A single, mediumcover application of $10 \mathrm{mg} \cdot \mathrm{L}^{-1} 2,4-\mathrm{D}$ timed directly APFD can be used in 'Marisol' and 'Mor' orchards with a history of severe fruit splitting, especially in years with heavy fruit load.

\section{Literature cited}

Agustí, M., A. Martinez-Fuentes, and C. Mesejo. 2002. Citrus fruit quality. Physiological basis and techniques of improvement. Agrociencia 4:1-16.
Almela, V., S. Zargoza, E. Primi-Millo, and M. Agusti. 1994. Hormonal control of splitting in 'Nova' mandarin fruit. J. Hort. Sci. 69:969-973.

Ashton, F.M. and T.J. Monaco. 1991. Weed science: Principles and practices. 3rd ed. Wiley, New York, NY.

Bar-Akiva, A. 1975. Effect of potassium nutrition on fruit splitting in Valencia orange. J. Hort. Sci. 50:85-89.

Barry, G.H. and J.P. Bower. 1997. Manipulation of fruit set and stylar-end fruit split in 'Nova' mandarin hybrid. Sci. Hort. 70:243-250.

Borroto, C.G., V.M. Lopez, A. Gonzalez, and L. Pyla. 1981. Orange drop under tropical conditions and measures of control. Proc. Intl. Soc. Citricult. 1: 268-271.

Bustan, A., Y. Erner, and E.E. Goldschmidt. 1995. Interactions between developing citrus fruits and their supportive vascular system. Ann. Bot. (Lond.) 76:657666.

Coggins, C.W., Jr. and H.Z. Hield. 1968. Plant growth regulators, p. 371-389. In: W. Reuther, L.D. Batchelor, and H.J. Webber (eds.). The citrus industry, Vol. II. Univ. California Press, Berkeley, CA.

Considine, J.A. and K. Brown. 1981. Physical aspects of fruit growth. Theoretical and analysis of distribution of surface growth forces in fruit relation to cracking and splitting. Plant Physiol. 68:371-376. 
Cronjé, P.J.R., O.P.J. Stander, and K.I. Theron. 2014. Fruit splitting in citrus. Hort. Rev. 41:177-200.

De Cicco, V., F. Intrigliolo, A. Ippolito, S. Vanadia, and A. Guiffrida. 1988. Factors in Navelina orange splitting. Proc. Intl. Soc. Citricult. 1:535-540.

El-Otmani, M., M. Agustí, M. Aznar, and V. Almela. 1993. Improving the size of 'Fortune' mandarin fruits by the auxin 2, 4-DP. Sci. Hort. 55:283-290.

Erickson, L.C. 1957. Compositional differences between normal and split Washington navel oranges. J. Amer. Soc. Hort. Sci. 70:257-260.

Erner, Y., Y. Kaplan, B. Artzi, and M. Hamon. 1993. Increasing citrus fruit size using auxins and potassium. Acta Hort. 329:112-119.

García-Luis, A., A.M.M. Duarte, M. Kanduser, and J.L. Guardiola. 2001. The anatomy of fruit in relation to the propensity of citrus fruit to split. Sci. Hort. 87:33-52.

Goren, R. 1993. Anatomical, physiologi$\mathrm{cal}$, and hormonal aspects of abscission in citrus. Hort. Rev. 15:145-182.

Greenberg, J., I. Kaplan, M. Fainzack, Y. Egozi, and B. Giladi. 2006. Effects of auxin sprays on yield, fruit size, splitting and the incidence of creasing of 'Nova' mandarin. Acta Hort. 727:249254.

Hanger, B.C. 1979. The movement of calcium in plants. Commun. Soil Sci. Plant Anal. 10:171-193.

Mesejo, C., A. Martínez-Fuentes, M. Juan, V. Almela, and M. Agustí. 2003. Vascular tissues development of citrus fruit peduncle is promoted by synthetic auxins. Plant Growth Regulat. 39:131135.

Mitchell, J.W. 1961. Fundamentals of plant development in the field of plant growth regulators. Bull. Torrey Bot. Club 88:299-312.

Mupambi, G. 2010. Studies to reduce the size of the Navel-end opening of Navel oranges. Univ. Stellenbosch, Stellenbosch, South Africa, MSc Thesis.

Rabe, E., P. Van Rensburg, H. Van Der Walt, and J. Bower. 1990. Factors influencing preharvest fruit splitting in Ellendale (C. reticulata). HortScience 25:1135 (abstr.).

Sdoodee, S. and R. Chiarawipa. 2005. Fruit splitting occurrence of Shogun mandarin (Citrus reticulata Blanco cv. Shogun) in southern Thailand and alleviation by calcium and boron sprays. Songklanakarin J. Sci. Technol. 27:719-730.

Stewart, W.S., J.L. Klotz, and H.Z. Hield. 1951. Effect of 2,4-D and related substances on fruit drop, yield, size and quality of Washington navel oranges. Hilgardia 21:161-193. 